\title{
Kebijakan Pemberian Kredit Terhadap Penetapan Jumlah Kredit (Studi Khasus Pada Ued-Sp Amanah Sejahtera Sungai Buluh Kecamatansingingi Hilirkabupaten Kuantan Singingi Propinsi Riau)
}

\author{
Zefriyenni $^{1}$, Ira Ufi Yuliana ${ }^{2}$ \\ Universitas Putra Indonesia \\ zefriyeni@yahoo.co.id
}

http://dx.doi.org/10.22202/iei.2014.v1i1.1443

\begin{abstract}
ABSTRAK
Penelitian ini dilakukan dengan tujuan untuk mengetahui penetapan jumlah kredit yang dipengaruhi oleh kebijakan pemberian kredit yang dilihat dari tingkat suku bunga kredit, jaminan kredit dan resiko kredit. Hasil penelitian ini diharapkan dapat memberikan masukan bagi pihak Ued-Sp Amanah Sejahtera dalam pengambilan langkah-langkah kebijakan pemberian kredit untuk mempertahankan dan meningkatkan tingkat likuiditas pada masa sekarang dan yang akan datang. Metode pengambilan sampel dilakukan dengan random yang menjadi nasabah UED - SP ANAH. Metode pengumpulan data dilakukan dengan wawancara dengan mengadakan Tanya jawab langsung dengan pihak UEDSP AMANAH. Sedangkan teknik analisa data menggunakan metode analisis 5C. Agar kredit yang diberikan dapat ditentukan layak atau tidak layak diberikan kepada debitur. Dari hasil analisis penelitian maka dapat disimpulkan debitur yang mendapatkan kredit dari Ued-Sp lebih banyak dibandingkan dengan yang tidak mendapatkan kredit, yang mendapatkan kredit sebesar 70\% (sebanyak 7 orang) sedangkan yang tidak mendapatkan kredit sebanyak 30\% ( sebanyak 3 orang).
\end{abstract}

Kata Kunci : Kebijakan, Jumlah Kredit ,5C

\section{PENDAHULUAN}

Salah satu dari produk Ued-Sp tersebut adalah kredit dimana hingga saat ini masih merupakan aktiva produktif yang memberikan pendapatan utama, kegagalansuatuUed-Sp mengandung resiko tinggi yang dapat mempengaruhi tingkat kesehatan dan kelangsungan hidup suatu Ued-Sp.

Ued-SpAmanah Sejahtera Desa Sungai Buluh Kecamatan Singingi Hilir Kabupaten kuantan Singing Propinsi Riau.menawarkan pinjaman berupa pinjaman usaha ekonomi desa (DUD) dan pinjaman simpan pinjam (SP). Debitur yang meminjam kredit kebanyakan merupakan nasabah lama dari Ued-Sp, sehingga dalam pemberian kredit akan lebih memudahkan pihak Ued-Sp dalam mengevaluasi kinerja debitur tersebut. Debitur yang diangkat disini memiliki jenis usaha yang berbeda-beda, diantaranya adalah pedagang, petani, PNS (Pegawai Negeri Sipil), kontraktor. Debitur disini mempunyai kebutuhan yang berbeda-beda dalam peminjaman kredit, diantaranya yaitu untuk tambahan modal dan untuk konsumtif sendiri.

Dalam melakukan kebijakan pemberian kredit Ued-Sp mengalami kesulitan dalam menganalisa debitur pada saat melaksanakan proses untuk memberikan fasilitas kredit (penyediaan dana) kepada calon debitur yang belum dikenal dengan baik, karena sangat sulit untuk mendapatkan informasi tentang calon debitur tersebut . kemungkinan calon debitur debitur yang sebelumnya telah memperoleh penyediaan dana dari lembaga keuangn lain.

Dan dalam kebijakan pemberian kredit Ued-Sp ada beberapa mengalami 
permasalahan atau kegagalan dalam melaksanakan kebijakanya dalam pemberian kredit kepada nasabah. Karna jaminan yang diberikan kepada pemohon tidak sesuai dengan jumlah pinjaman atau melihat kemampuan keuangan dari pihak peminjam sangat tidak memungkinkan dengan jumlah usulan kredit.

Oleh karena itu sebelum melakukan pemberian kredit perusahaan harus memperhatikan unsur " 5C " yaitu character, capacity, capital, condition, dan collateral. Pemberian kredit yang tidak memperhatikan kebijaksanaan dan prosedur yang ada akan mengundang timbulnya penyimpanganpenyimpangan yang lain. Salah satu hal yang paling penting dalam pemberian kredit yaitu dengan melakukan evaluasi kembali atas kredit yang diduga akan bermasalah, sehingga kredit tersebut dapat diselamatkan dan terhindar dari kemacetan.

Dengan adanya skim tersebut maka UedSplebih mudah menilai resiko kredit yang diberikannya.Namun dalam kebijakan pemberian kredit yang telah dilalui oleh beberapa penilaian-penilaian tertentu akan mempengaruhi penetapan jumlah kredit itu sendiri, dan jumlah kredit ini juga akan disesuaikan kepada suku bunga kredit dan jaminan kredit, agar kebijakan dalam pemberian kreditmampu memperkecil risikorisiko terhadap jumlah kredit yang diberikan.

\section{LANDASAN TEORI}

\section{Pengertian kredit}

Menurut pengertian nasional $\boldsymbol{U} U$ No. 7 tahun 1992 tentang perbankan Kredit adalah: Penyediaan uang atau tagihan yang dapat dipersamakan dengan itu, berdasarkan persetujuan atau kesepakatan pinjam meminjam antara bank dengan pihak lain yang mewajibkan pihak peminjam untuk melunasi utangnya setelah jangka waktu tertentu dengan jumlah bunga, imbalan atau pembagian hasil keuntungan. Dalam perkreditan adapun lembaga keuangan yang bergerak dibidang perkreditan yaitu Usaha
Ekonomi Desa Simpan-Pinjam (Ued-Sp) yang merupakan lembaga yang bergerak di bidang simpan pinjam dan merupakan milik masyarakat desa/kelurahan yang diusahakan serta dikelola oleh masyarakat desa/kelurahan.

\section{Jenis-jenis Kredit}

Menurut Ismail (2010:99), secara umum jenis kredit yang disalurkan oleh bank dan dilihat dari berbagai segi yang dijelaskan sebagai berikut:

1. Berdasarkan penggunaannya

a. Kredit investasi

Kredit investasi ini merupakan kredit yang diberikan oleh bank kepada debitur untuk penggadaan barangbarang modal yang mempunyai nilai ekonomis lebih dari satu tahun

b. Kredit modal kerja

Kredit modal kerja merupakan kredit yang digunakan untuk memenuhi kebutuhan modal kerja yang biasanya habis dalam satu siklus usaha. Kredit modal kerja ini, biasanya diberikan dalam jangka pendek.

c. Kredit konsumtif

Kredit komsumtif adalah kredit yang diberikan kepada nasabah untuk membeli barang atau jasa untuk keperluan pribadi dan untuk digunakan keperluan usaha.

2. Berdasarkan Jangka Waktu

a. Kredit jangka pendek

Kredit ini merupakan kredit yang diberikan dengan jangka waktu maksima 1 satu tahun. Kredit tersebut biasanya diberikan oleh bank untuk membiayai modal kerja perusahaan yang mempunyai siklus usaha dalam satu tahun.

b. Kredit jangka menengah

Kredit jangka menengah merupakan kredit yang diberikan dengan jangka waktu antara satu tahun sampai tiga tahun.

c. Kredit Jangka Panjang 
Kredit jangka panjang adalah kredit yang jangka waktunya lebih dari tiga tahun, Kredit ini diberikan untuk kredit investasi.

3. Berdasarkan cara penarikannya

a. kredit sekaligus

kredit sekaligus bias disebut dengan aflopend credit merupakan kredit yang dicairkan sekaligus sesuai dengan Plafon kredit yang disetujui. Kredit tersebut bisa dicairkan secara tunai.

b. kredit bertahap

kredit bertahap merupakan kredit yang pencairannya tidak sekaligus akan tetapi dilakukan secara bertahap 2,3,4, kali pencairan dalam masa kredit.

c. Kredit rekening koran

Kredit rekening koran merupakan kredit yang menyediakan dananya dilakukan melalui pemindah bukuan.

4. Berdasarkan dari sektor usaha

a. Sektor industri

Kredit yang diberikan kepada nasabah yang bergerak dalam sektor industri.

b. Sektor perdagangan.

Kredit ini, diberikan kepada pengusaha yang bergerak dalam bidang perdagangan, baik perdagangan kecil, menengah, dan perdagangan besar.

5. Berdasarkan dari segi jaminan

a. Kredit dengan jaminan

Kredit dengan jaminan merupakan jenis kredit yang didukung dengan jaminan (agunan).

b. Kredit tanpa jaminan

Kredit tanpa jaminan merupakan kredit yang diberikan kepada debitur tanpa dukungan dan jaminan.

6. Berdasarkan dari jumlahnya
a. Kredit UMKM
Kredit UMKM merupakan kredit yang diberikan kepada pengusaha dengan sekala usaha kecil.

b. Kredit UKM
Kredit UKM merupakan kredit yang diberikan kepada pengusaha dengan batasan antara Rp 50.000.000,- dan tidak melebihi Rp 350.000.000,sehingga bank dapat memberikan kepada pemohon kreditnya. Kredit UKM antara lain kredit untuk koperasi, pengusaha kecil (perdagangan, toko, grosir).

c. Kredit koporasi

Jenis kredit ini merupakan kredit yang diberikan kepada debitur dengan jumlah besar dan diperuntukkan kepada debitur besar (koporasi).

\section{Kebijakan Pemberian Kredit}

MenurutRivai (2006:97) ketentuan kebijakan kredit perlu ditetapkan agar setiap bank memiliki dan menerapkan kebijakan kredit yang baik, yang :

1. Mampu mengawasi portofolio kredit secara keseluruhan dan menetapkan standardalam proses pemberian kredit secara individual.

2. Memiliki standar/ukuran yang mengandung pengawasan intern pada semuatahapan proses perkreditan.

\section{Prinsip-Prinsip Pemberian Kredit}

Menurut Kasmir (2013:95) Dalam melakukan penilaian kriteria-kriteria serta aspek penilaiannya tetap sama. Begitu pula dengan ukuran-ukuran yang ditetapkan sudah menjadi standar penilaian setiap bank. Biasanya criteria penilaian yang harus dilakukan oleh bank untuk mendapatkan nasabah yang benar-benar menguntungkan dilakukan dengan analisis 5C yaitu:

1. Character

Suatu keyakinan bahwa sifat atau watak dari orang-orang yang akan diberikan kredit benar-benar dapat dipercaya

2. Capacity

Untuk melihat nasabah dalam kemampuannya dalam bidang bisnis yang dihubungkan dengan pendidikannya 
3. Capital

Untuk melihat penggunaan modal apakah efektif, dilihat laporan keuangan (neraca dan laporan laba rugi) dengan melakukan pengukuran seperti dari segi likuiditas, solvabilitas, rentabilitas, dan ukuran lainnya

4. Colleteral

Merupakan jaminan yang diberikan calon nasabah baik yang bersifat fisik maupun.non fisik.

5. Condition

Dalam menilai kredit hendaknya juga dinilai kondisi ekonomi dan politik sekarang dan dimasa yang akan datang sesuai sektor masing-masing, serta prospek usaha dari sektor yang ia jalankan.

\section{Prosedur Pengajuan Kredit}

Secara umum prosedur pengajuan kredit untuk produktif menurut Kasmir (2012:110) adalah sebagai berikut :

1. Menilai sampai sejauh mana syaratsyarat kredit maupun kewajiban

2. pembayaranbunga, angsuran, dan kewajiban-kewajiban lainnya telah terpenuhi debitur sebagaimana mestinya.

3. Menilai perkembangan usaha debitur dari waktu ke waktu yang berkaitan denganresiko yang dihadapi oleh bank.

4. Membantu bank dalam mengambil langkah-langkah preventif yang diperlukan.

\section{Risiko Kredit}

MenurutKasmir (2013:104) risiko merupakan kondisi dan situasi yang akan dihadapi di masa yang akan datang yang sangat besar pengaruhnya terhadap perolehan laba bank. Dalam praktiknya banyak jumlah kredit yang disalurkan juga harus memperhatikan kualitas kredit tersebut.

\section{Faktor Penyebab Terjadinya Risiko Kredit}

Menurut Gatot Suparmono (2009 : 269), secara umum terdapat dua faktor penyebab terjadinya Risiko Kredityaitu :

1. Faktor yang berasal dari nasabah
a. Nasabah menyalah gunakan kredit
b. Nasabah kurang mampu mengelola usahanya
c. Nasabah beritikad tidak baik

2. Faktor yang berasaldari bank
a. Kualitas pejabat bank
b. Persaingan antar bank
c. Hubungan intern bank
d. Pengawasan bank

\section{Faktor-faktor yang Mempengaruhi Suku Bunga}

Menurut Kasmir (2013:115) faktor-faktor yang mempengaruhi besar kecilnya penetapan suku bunga adalah sebagai berikut

1. Kebutuhan dana

Apabila bank kekurangan dana,sementara permohonan pinjaman meningkat, maka yang dilakukan oleh bank agar dana tersebut cepat terpenuhi dengan meningkatkan suku bunga simpanan.

\section{Persaingan}

Dalam memperebutkan dana simpanan, maka disamping faktor promosi,yang paling utama pihak perbankan harus memperhatikan pesaing.

3. Kebijakan pemerintah

Bunga simpanan maupun bunga pinjaman kita tidak boleh melebihi bunga yang sudah ditetapkan oleh pemerintah.

4. Target laba yang diinginkan

Jika laba yang diinginkan besar,maka bunga pinjaman ikut besar dan sebaliknya.

5. Jangka waktu

Semakin panjang jangka waktu pinjaman,akan semakin tinggi bunganya, hal ini disebabkan besarnya kemungkinan risiko di masa mendatang.

6. Kualitas jaminan

Semakin likuid jaminan yang diberikan, semakin rendah bunga kredit yang dibebankan dan sebaliknya. 
7. Reputasi perusahaan

Bonafiditas suatu perusahaan yang akan memperoleh kredit sangat menentukan tingkat suku bunga yang akan dibebankan nantinya.

8. Produk yang kompetitif

Produk yang yang dibiayai tersebut laku di pasaran, bunga kredit yang diberikan relatif rendah jika dibandingkan dengan produk yang kurang kompetitif.

9. Hubungan baik

Nasabah utama biasanya mempunyai hubungan yang baik dengan pihak bank sehingga dalam penentuan suku bunganya pun berbeda dengan nasabah biasa.

10. Jaminan pihak ketiga

Pihak yang memberikan jaminan bonafid, baik dari segi kemampuan membayar, nama baik maupun loyalitasnya terhadap bank, maka bunga yang dibebankan pun berbeda.

\section{Kerangka Pikir}

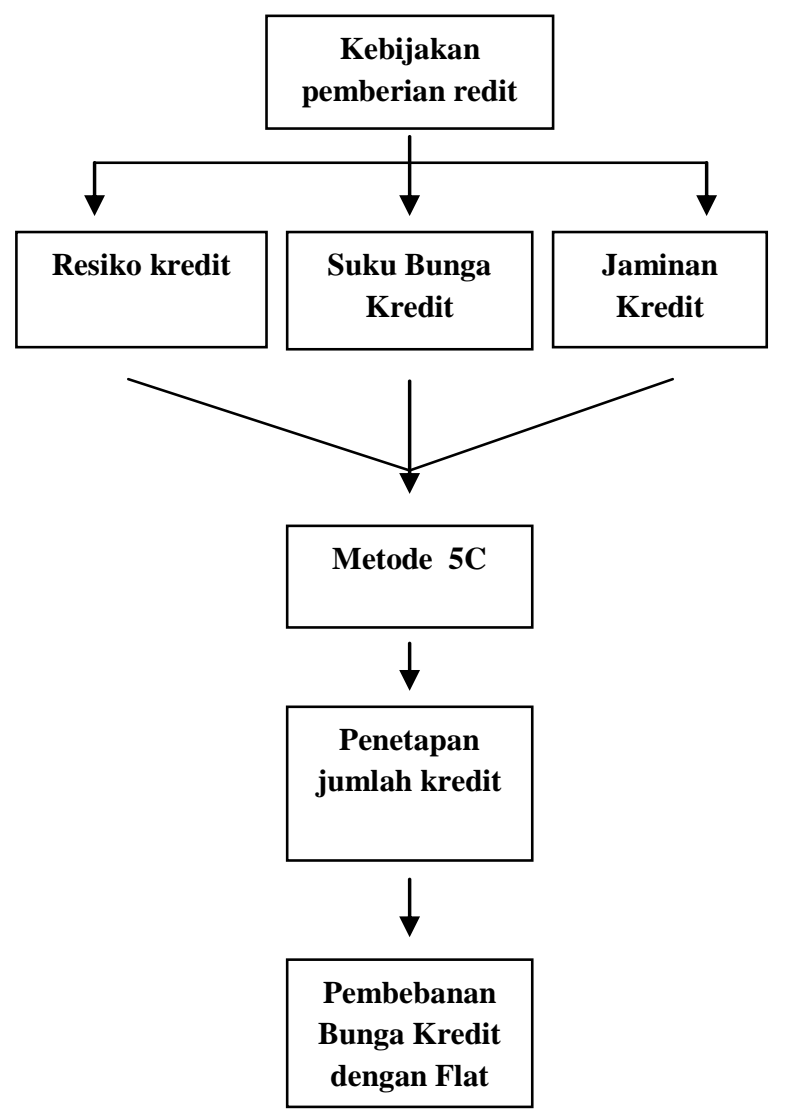

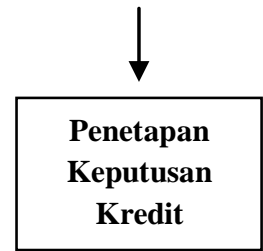

Gambar. Kerangka fikir

\section{METODOLOGI PENELITIAN}

\section{Variabel Penelitian}

Variabel penelitian adalah objek penelitian yang menjadi titik perhatian, untuk memudahkan kita dalam memahami dan membahas variabel-variabel yang akan digunakan penulis dalam penelitian ini maka perlu kita ketahui dan tentukan yang terdapat dalam penelitian ini untuk dibahas selanjutnya, variabel-variabel yang akan dibahas dengan mengunakan variabel 5C yaitu:

\section{Character}

Suatu keyakinan bahwa, sifat atau watak dari orang-orang yang akan diberikan kredit benar-benar dapat dipercaya.

2. Capacity

Untuk melihat nasabah dalam kemampuannya dalam bidang bisnis yang dihubungkan dengan pendidikannya, kemampuan bisnis juga diukur dengan kemampuannya dalam memahami tentang ketentuan-ketentuan pemerintah.

3. Capital

Untuk melihat penggunaan modal apakah efektif, dilihat laporan keuangan (neraca dan laporan laba rugi) dengan melakukan pengukuran seperti dari segi likuiditas, solvabilitas, rentabilitas, dan ukuran lainnya. Capital juga harus dilihat dari sumber mana saja modal yang ada sekarang ini.

4. Colleteral

Merupakan jaminan yang diberikan calon nasabah baik yang bersifat fisik maupunnon fisik. Jaminan hendaknya melebihi jumlah kredit yang diberikan.

5. Condition 
Dalam menilai kredit hendaknya juga dinilai kondisi ekonomi dan politik sekarang dan dimasa yang akan datang sesuai sektor masing-masin.

\section{Sumber Data}

Sumber data yang digunakan dalam penelitian ini adalah :

1. Data Primer

Merupakan data yang secara langsung penulis peroleh dari objek penelitian dengan secara langsung mendatangi perusahaan baik secara wawancara, pengamatan maupun dari daftar pertanyaan.

2. Data Sekunder

Merupakan data-data yang digunakan untuk mendukung data primer berupa referensi-referensi baik dari buku-buku pedoman literature dan tulisan ilmiah lainnya yang berhubungan.

\section{Teknik Pengumpulan Data}

Untuk menghimpun data yang dibutuhkan maka digunakan metode pengumpalan data sebagai berikut :

1. Penelitian Lapangan

Penelitian langsung ke Ued-Sp yang di lakukan melalui wawancara terhadap pihak yang terkait.

2. Metode pustaka

Metode yang dilakukan dengan cara membaca Buku, majalah, jurnal yang berkaitan dengan masalah yang dibahas.

\section{Metode Analisis Data}

Untuk mengolah data dan menganalisa data yang telah ada maka peneliti menggunakan prosedur analisis data yaitu :

1. Metode Kualitatif

Dalam metode ini penulis melakukan suatu analisa deskriptif yaitu dengan membandingkan antara bacaan dengan kenyataan yang diambil dilapangan, sehingga dapat menghasilkan solusi yang baik dan optimal. Dalam metode ini teknik yang digunakan untuk menganalisis kebijakan pemberian kredit kepada debitur, yaitu menggunakan alat analisis 5C.

2. Metode Kuantitatif

Dalam metode ini penulis menggunakan metode Flat Rate kuantitatif berdasarkan angka-angka dengan menggunakan rumus sebagai berikut : Menurut Kasmir (2013 : 121) dalam metode flat rate, yaitu pembebanan bunga setiap bulan tetap dari jumlah pinjamannya, demikian pula pokok pinjaman setiap bulan juga dibayar sama sehingga cicilan setiap bulan sama sampai kredit tersebut lunas.

Adapun rumus yang digunakan untuk menghitung pembebanan bunga kredit dengan metode Flat rate adalah :

1. Menghitung Pokok Pinjaman

$$
P J=\frac{\text { JUMLAHPINJAMAN }}{\text { JANGKAWAKTU }}
$$

2. Menghitung Bunga

$$
B G=\frac{B U N G A x N O M I N A L P I N J A M A N}{12 B U L A N} x 1
$$

\section{ANALISA DAN HASIL}

\section{Hasil Analisis}

Dari hasil analisis pada Ued-Sp Amanah Sejahtera pemberian kredit akan dianggap sukses apabilapenerimaankredit yang bersangkutan dapat melunasi pinjaman serta bunganya tepat pada waktu yang ditetapkan tanpa menggang gu kontinuitas dan perkembangan usahanya. Maka sangat diperlukan beberapa pemantauan untukmenentukanapakahkreditdapatdiberika natauditolak, Dengan penilaian analisis 5C yaitu:

1. Character: dimana setiap karakter dari pemohon Ued-Sp mayoritas berkepribadian baik, dan memiliki hubungan baik dengan masyarakat disekitar, dan begitu juga dengan pihak ke tiga.

2. Capacity: dari latar belakang debitur kebanyakan debitur usahanya bergerak dibidang perdagangan, sebagai pemilik 
dan sebagai pengelola usaha, dimana penghasilan debitur setiap bulannya dapat kover angsuran setiap bulannya kepada pihak Ued-Sp Amanah Sejahtera.

3. Capital: kebanyakan modal yang di miliki debitur merupakan modal sendiri dan modal pinjaman dari Ued-Sp Amanah Sejahtera.

4. Collateral: Setiap debitur yang ada di Ued-Sp agunan yang digunakan kebanyakan Surat kendaraan, dan SKT, dan jaminan yang digunakan jumlahnya sangat mendukung dengan jumlah pinjaman debitur. jika jaminan kredit tidak mewakili jumlah kredit yang diajukan jumalah kredit dapat diturunkan atau disesuaikan.

5. Condition: dimana kondisi dari usaha para debitur usaha yang dilakukan sangat mendukung dalam perekonomian debitur, dan kebanyakan pembayarannya secara tunaidan adapun piutang jangka pendek.

Dalam menggunakan metode Flat Rate yaitu pembebanan bunga perbulannya kepada debitur yang bertujuan untuk menetapkan bunga sesuai dengan usulan kredit, dan dilihat kemampuan debitur dalam pembayaran total angsuran setiap bulannya apakah debitur dapat melunasi jumlah bunga yang dibebankan melalui Usulan kredit yang diberikan kepada pihak Ued-Sp. Jika pendapatan perbulannya dan jaminan kredit dapat kover angsuran dan bunganya maka usulan kredit diputuskan bahwa pemohon kredit disetujui atau diterima.

\section{KESIMPULAN DAN SARAN}

\section{Kesimpulan}

Berdasarkan hasil dari penelitian yang dilakukan penulis maka dapat disimpulkan sebagai berikut:

1. Dalam pemberian kredit pada Ued-Sp Amanah Sejahtera telah sesuai dengan prinsip yang telah diterapkan dengan menggunakan metode analisis 5C yaitu
Character, Capacity, Capital, Collateral, dan Condition. Dari hasil analisis debitur yang mendapatkan kredit sebanyak 7 orang $(70 \%)$ sedangkan yang tidak mendapatkan kredit sebanyak 3 orang (30\%), hal ini berarti yang mendapatkan kredit lebih banyak dibandingkan yang tidak mendapatkan kredit.

2. Dalam pemberian kredit pada Ued-Sp Amanah Sejahtera jika pemberian kredit tidak dilakukan dengan baik yaitu dengan menggunakan metode analisis 5C, maka akan menimbulkan resiko yang sangat tinggi dalam pemberian kredit yang dapat menimbulkan kredit macet pada nasabah Ued-Sp Amanah Sejahtera.

3. Dalam kebijakan pemberian kredit pada Ued-Sp Amanah Sejahtera penerapan tingkat suku bunga kredit dihitung dengan menggunakan metode pembebanan suku bunga.

4. Dalam kebijakan pemberian kredit pada Ued-Sp Amanah Sejahtera penerapan jaminan kredit ditetapkan setelah adanya penilaian terhadap debitur dan jumlah kredit yang diajukan oleh debitur, jika jaminan kredit tidak mewakili jumlah kredit yang diajukan jumalah kredit dapat diturunkan atau disesuaikan.

5. Dalam penetapan jumlah kredit kerhadap debitur pada Ued-Sp Amanah Sejahtera sangat dipengaruhi oleh kebijakan pemberian kredit yang dilihat dari resiko kredit, jaminan kredit dan suku bunga kredit maka dari sana dapat ditentukan penetapan jumlah kredit yang akan disetujui atau sebaliknya permihonan kredit ditolak.

\section{Saran}

Berdasarkan hasil dari penelitian yang dilakukan penulis maka dapat disarankan sebagai berikut :

1. Sebaiknya Ued-Sp Amanah Sejahtera Desa Sungai Buluh mempertegas penerapan prinsip kehati-hatian yang telah ditetapkan pada prosedur pemberian kreditnya dari prosedur 
permohonan kredit sampai dengan prosedur penyelamatan kredit bermasalah.

2. Bagi debitur agar dalam mengajukan kredit terhadap kreditur disesuaikan dengan kemampuan membayar kembali pinjamannya.

3. Bagi peneliti selanjutnya dengan judul yang berbeda supaya dalam menganalisis pemberian kredit lebih teliti dan lebih menambah variabel yang dianggap perlu dan memperluas sampel penelitian, dan data penelitian.

\section{DAFTAR PUSTAKA}

Abdullah, Thamrin dan Tantri, Francis. Bank dan Lembaga keuangan. Jakarta: PT Raja Grafindo Persada, (2013).

Aqidah NurAriani. Implikasi Kebijakan Pemberian Kredit dan Pengaruh Loan To Deposit Ration Terhadap Non Performing Loan. Universitas Hasanuddin. Makasar, (2011).

http://kelascakuntansi/2011/.blogspot.com

http://www.kajianpustaka.com

http://kelastambahan.wordpress.com/tag/kre dit-menurut-ahli

http://dinulislami.blogspot.com/2013/02/jeni s-jenis-kredit.html

http://kelascakuntansi2011.blogspot.com/201 3/01/analisis-kebijaksanaanpemberian-kredit.

http://www.kajianpustaka.com/2013/02/peng ertian-unsur-dan-fungsi-kredit.html

http://profiledesacikondang.blogspot.com/20 10/05/profil-usaha-ekonomi-simpanpinjam. http://id.shvoong.com/businessmanagement/accounting/2358872pengertian-kredit.

Ikatan Akuntansi Indonesia, dalam PSAK No. 31

Ismail. ManajemenPerbankan. Jakarta: Kencana, (2010).

Kasmir. 2012. Manajemen Perbankan. Jakarta: Ghalia Indonesia.

Kasmir. (2013). Bank Dan Lembaga Keuangan Lainnya. Jakarta : PT. Raja Grafindo Persada, (2010).

Lady Frengky. Evaluasi Keleyekan Pemberian Kredit Oleh PT. BPR Artha Panggung Perkasa

Trenggelek.Universitas Muhammadiyah. Malang, (2008).

Mayang Sartin. Analisis Kebijakan Pemberian Kredit Pada Calon Nasabah. Pt Bank BRI tbk Cabang Kota Gorontalo. Universitas Gunadarma. Gorontalo, (2011).

Pratiwi. Analisis Kebijakan Pemberian Kredit Terhadap Non Performing Loan pada Bank Tabungan Negara (persero), Tbk Cabang Makassar. Universitas Hasanuddin Makassar, (2012).

Rachmat, Firdaus dan Ariyanti, Maya. Manajemen Perkreditan Bank Umum: Teori, Masalah, Kebijakan dan Aplikasi Lengkap dengan Analisis Kredit. Bandung: Alfabeta, (2009).

Rivai.Veithzal. Credit Management Hand book. Jakarta : PT. Raja Grafindo Persada,(2006).

Silvianti Ricka. Implikasi Kebijakan Pemberian Kredit dan Resiko Kredit 
Ditinjau sari Tingkat Suku bunga Kredit dan Jaminan Kredit Terhadap Penetapan Jumlah Kredit.Universitas Putra Indonesia "YPTK". Padang, (2013).

Supramono, Gatot. Perbankan dan Masalah Kredit. Jakarta : PT. RinekaCipta, (2009).

Sutomo. 2009. Aspek-aspek Hukum Perbankan Pada Bank. Bandung: Alfabeta.

Taswan.2013.Akuntansi Perbankan. Yogyakarta: UPP STIM YKPN.

UU No.7 tahun 1992 tentang perbankan.

UU No. 14 tahun 1967 tentang pokok perbankan pasal 24 (1)

UU Pokok Perbankan Nomor 10 Pasal 5 ayat (1) tahun 1998. 